\title{
One-Step Synthesis of Carbon Nitride Nanosheets for Photoremediation of Toxic Organic Dyes Waste in Aquatic Environment
}

\section{Sintesis Satu Tahap Carbon Nitride Nanosheets untuk Fotoremediasi Limbah Pewarna Organik Beracun di Lingkungan Perairan}

\author{
Huwaida Ikbar a,1, Muhammad Hakim Muzakky a,2, Harry Pramudya Rivelino a,3, Anatta Wahyu \\ Budiman ${ }^{\mathrm{a}, 4, *}$

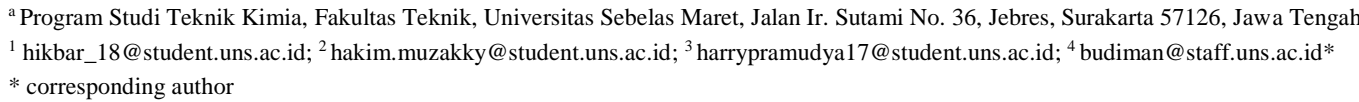

\section{Article histor}

Received November 11, 2020

Revised January 05, 2021

Accepted February 01, 2021

Keywords

g- $\mathrm{C}_{3} \mathrm{~N}_{4}$

Carbon nitride nanosheets

Photocatalytic

Photoremediation

\section{ABSTRACT}

Graphitic Carbon Nitride $\left(g-C_{3} N_{4}\right)$ has been taking scientists' attention because of its potential applications as a catalyst for organic synthesis, electrodes, photocatalyst, and hydrogen storage material. The $g-C_{3} N_{4}$ also has excellent chemical stability, unique optical characteristics, and high thermal stability. Moreover, it only consists of carbon and nitrogen elements that make it safer for the environment than metal-based catalysts. Various techniques have been introduced to improve $g-C_{3} N_{4}$ photocatalytic efficiency combined with other semiconductors and modify morphology like porous $g-C_{3} N_{4}$ or nanostructures $g-C_{3} N_{4}$. Compared with $g-C_{3} N_{4}$ bulk, $g-C_{3} N_{4}$ Nanosheets have many advantages, including high efficiency, low cost, environmentally friendly, and easy to produce on a large scale. This review contains an overview of the one-step synthesis method from melamine and ammonium chloride for $g-C_{3} N_{4}$ nanosheets and characteristics and potential applications in dyes photoremediation.

This is an open access article under the CC-BY-SA license.

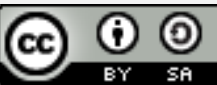

\section{Pendahuluan}

Berbagai permasalahan lingkungan yang diakibatkan oleh kegiatan industri seperti pencemaran tanah dan air menyebabkan semakin meningkatnya minat pada upaya penanganan permasalahan lingkungan. Remediasi katalitik limbah organik dengan bantuan sinar matahari menjadi salah satu solusi alternatif yang menjanjikan untuk mencapai lingkungan yang bebas kontaminan. Selain proses ini hanya membutuhkan energi matahari yang melimpah dan bersumber dari sumber daya yang berkelanjutan, proses ini juga mengikuti prinsip green chemistry yang ramah lingkungan [1].

Dalam beberapa dekade terakhir, fotokatalis dianggap sebagai alternatif yang efektif dalam menghadapi masalah berkurangnya sumber energi dan masalah lingkungan. Hal tersebut dikarenakan harganya yang murah, bersih, dan berkelanjutan. Belakangan ini penelitian mengenai fotokatalitik untuk perbaikan lingkungan didominasi oleh penggunaan titanium dioksida $\left(\mathrm{TiO}_{2}\right)$. Namun, para peneliti menemukan bahwa band gap yang lebar $(3,2 \mathrm{eV})$ dan rekombinasi muatan pada $\mathrm{TiO}_{2}$ membuat efisiensi kuantum $\mathrm{TiO}_{2}$ sangat rendah sehingga pada prakteknya, aplikasi $\mathrm{TiO}_{2}$ tidak mudah [2].

Katalis Graphitic Carbon nitride $\left(\mathrm{g}-\mathrm{C}_{3} \mathrm{~N}_{4}\right)$ menjadi perhatian para ahli bidang fotokatalis setelah dilaporkan memiliki kemampuan untuk memproduksi hidrogen dari air. Katalis g- $\mathrm{C}_{3} \mathrm{~N}_{4}$ memiliki 
band gap yang sempit $(2,7 \mathrm{eV})$ sehingga berpotensi untuk menyerap lebih banyak cahaya tampak dibandingkan material semikonduktor lainnya. Katalis $\mathrm{g}-\mathrm{C}_{3} \mathrm{~N}_{4}$ juga memiliki kestabilan kimia yang baik, karakteristik optik khusus, dan kestabilan termal tinggi yang menjadikannya sebagai fotokatalis yang menjanjikan dalam proses fotoremediasi limbah organik menggunakan sinar tampak [3]. Katalis $\mathrm{g}_{-} \mathrm{C}_{3} \mathrm{~N}_{4}$ hanya terdiri dari elemen karbon dan nitrogen tanpa campuran elemen logam sehingga aman untuk lingkungan. Dalam pengaplikasian, g- $\mathrm{C}_{3} \mathrm{~N}_{4}$, selain bertujuan untuk proses fotokatalitik, $\mathrm{g}-\mathrm{C}_{3} \mathrm{~N}_{4}$ juga memungkinkan untuk diaplikasikan dalam sistem heterogen sebagai katalis heterogen [4-6].

Tujuan utama dari ulasan ini adalah untuk mengetahui potensi sintesis satu tahap senyawa katalis g- $\mathrm{C}_{3} \mathrm{~N}_{4}$ nanosheets dari campuran prekursor melamin dan ammonium klorida. Katalis g- $\mathrm{C}_{3} \mathrm{~N}_{4}$ nanosheets dipilih karena dikenal sebagai katalis organik yang memiliki kestabilan kimia yang baik, karakteristik optik khusus, kestabilan termal yang tinggi, dan aman bagi lingkungan serta biaya produksi yang cukup murah [7]. Pada ulasan ini akan dijelaskan carbon nitride nanosheets mulai dari proses sintesis, karakterisasi, fotokatalitik, dan aplikasi khususnya kemampuan dalam meremediasi limbah pewarna organik untuk perbaikan lingkungan perairan.

\section{Metode Penulisan}

Desain penelitian ini adalah narrative review. Studi narrative review merupakan cara yang digunakan untuk mengumpulkan data mengenai topik tertentu yang bisa didapatkan dari karya-karya ilmiah yang pernah terpublikasi yang bertujuan untuk menghindari duplikasi, mencari inovasi baru, dan untuk memperkuat suatu ide.

Penelusuran artikel publikasi melalui laman pencarian google scholar, scopus, dan researchgate menggunakan kata kunci yang dipilih yakni carbon nitride nanosheets, $\mathrm{g}-\mathrm{C}_{3} \mathrm{~N}_{4}$, fotokatalitik, dan fotoremediasi. Artikel atau jurnal yang sesuai dengan kriteria pemilihan jurnal diambil untuk selanjutnya dianalisis. Narrative review ini menggunakan literatur terbitan tahun 2010-2020 yang dapat diakses full text dalam format portable document format (PDF). Kriteria jurnal yang diulas adalah artikel jurnal penelitian berbahasa Indonesia dan Inggris dan bukan literature review.

\section{Hasil dan Pembahasan}

\subsection{Graphitic carbon nitride $\left(\mathrm{g}-\mathrm{C}_{3} \mathrm{~N}_{4}\right)$}

Fotokatalisis berbasis semikonduktor dengan bantuan cahaya matahari menarik perhatian yang luar biasa dalam pencemaran lingkungan dan krisis energi. Di antara semua semikonduktor, g- $\mathrm{C}_{3} \mathrm{~N}_{4}$ menunjukkan sifat yang baik yaitu ramah lingkungan, struktur, dan properti elektronik yang unik seperti band gap yang sempit dan respon cahaya tampak yang membuat $\mathrm{g}-\mathrm{C}_{3} \mathrm{~N}_{4}$ bekerja dengan baik dalam aktivitas fotokatalitik. Katalis $\mathrm{g}-\mathrm{C}_{3} \mathrm{~N}_{4}$ hanya terdiri dari elemen karbon dan nitrogen sehingga lebih aman untuk lingkungan dibandingkan dengan katalis berbasis logam. Namun $\mathrm{g}_{-} \mathrm{C}_{3} \mathrm{~N}_{4}$ memiliki kekurangan dalam hal luas permukaan spesifiknya rendah, penyerapan sinar matahari terbatas, dan cepat rekombinasi muatan yang membatasi efisiensi fotokatalitik [8]. Sejauh ini, berbagai strategi telah diusulkan untuk menangani kekurangan di atas, termasuk doping heteroatom, kekosongan karbon dan nitrogen, konstruksi heterostruktur, dan perancangan struktur nano, seperti nanosheets, nanorods, nanotube, dan nanosfer. Komposisi, struktur, dan karakteristik kimia sifat $\mathrm{g}-\mathrm{C}_{3} \mathrm{~N}_{4}$ secara intensif dipengaruhi oleh reaksi atmosferik [9].

Para peneliti menemukan dua jalur utama pembuatan $\mathrm{g}-\mathrm{C}_{3} \mathrm{~N}_{4}$ yang telah dikembangkan sebagai bulk dan lapisan tipis deposit. Katalis carbon nitride berjenis bulk biasanya memiliki bentuk kristal, sedangkan lapisan tipis deposit yang terbentuk biasanya berbentuk amorf dan tampak menunjukkan sifat mekanik, tribology, dan optik yang unik. Berbagai teknik sintesis $g-\mathrm{C}_{3} \mathrm{~N}_{4}$ telah dilakukan seperti lapisan tipis deposit, solvotermal, kalsinasi, reaksi keadaan padat, hidrotermal, sintesis ionothermal, satu tahap nitridasi, keadaan padat, sonochemical, dan kondensasi termal [10]. Proses kondensasi termal dari prekursor yang kaya akan nitrogen seperti melamin, cyanamide, dicyanamide, dan urea telah menjadi cara yang paling menjanjikan karena prosesnya yang sederhana dan bahan bakunya yang mudah ditemukan.

Polimer carbon nitride grafitik berbasis triazin dan poly-heptaazine imide memiliki bentuk dan sifat yang paling mendekati dari g- $\mathrm{C}_{3} \mathrm{~N}_{4}$ yang ideal [11]. Katalis $\mathrm{g}_{-} \mathrm{C}_{3} \mathrm{~N}_{4}$ juga memungkinkan untuk 
disintesis baik dari urea yang melalui proses poliadisi langsung menjadi melamin atau langsung dari kondensasi termal melamin $[6,12]$. Selama proses sintesis $\mathrm{g}_{-} \mathrm{C}_{3} \mathrm{~N}_{4}$, perlu dijaga kondisinya agar tetap zero-oxygen karena sedikit oksigen dapat menghasilkan gas ammonia dan $\mathrm{NO}_{\mathrm{x}}$ yang beracun [6]. Secara penilaian, penggunaan melamin menjadi yang paling sederhana dan aman dalam proses sintesis $\mathrm{g}_{-} \mathrm{C}_{3} \mathrm{~N}_{4}$. Namun $\mathrm{g}_{-} \mathrm{C}_{3} \mathrm{~N}_{4}$ bulk mempunyai kemampuan fotokatalitik yang kurang memadai dikarenakan efisiensi kuantum yang kurang baik serta laju rekombinasi yang tinggi. Untuk meningkatkan performanya, beberapa peneliti telah melakukan bermacam-macam metode modifikasi bentuk morfologi $\mathrm{g}-\mathrm{C}_{3} \mathrm{~N}_{4}$ [13].

\subsection{Sintesis g- $\mathbf{C}_{3} \mathbf{N}_{\mathbf{4}}$ Nanosheets Secara Konvensional}

Terlepas dari semua potensi carbon nitride seperti yang disebutkan sebelumnya, masalah luas permukaan yang rendah (di bawah $10 \mathrm{~m}^{2} / \mathrm{g}$ ) masih perlu dihadapi [14]. Pembentukan $\mathrm{g}-\mathrm{C}_{3} \mathrm{~N}_{4}$ nanosheets merupakan cara yang menjanjikan untuk meningkatkan luas permukaan serta sifat optik dan elektronik g- $\mathrm{C}_{3} \mathrm{~N}_{4}$. Modifikasi bentuk nanosheet dari carbon nitride diharapkan mampu menciptakan sifat mekanik, termal, dan kimia yang berbeda terkait dengan peningkatan kinerja g$\mathrm{C}_{3} \mathrm{~N}_{4}$. Katalis $\mathrm{g}-\mathrm{C}_{3} \mathrm{~N}_{4}$ bulk terdiri dari beberapa lapisan struktur planar yang antar lapisan diikat oleh gaya Van Der Waals. Usaha pemisahan beberapa lapis $\mathrm{g}_{-} \mathrm{C}_{3} \mathrm{~N}_{4}$ menjadi satu lapisan (nanosheet) terinspirasi dari pembentukan grapheme dari graphite menggunakan metode Hummer [15]. Proses pemisahan beberapa lapisan $\mathrm{g}-\mathrm{C}_{3} \mathrm{~N}_{4}$ diilustrasikan pada Gambar 1. Penambahan beberapa bahan kimia bertujuan untuk memecah ikatan-ikatan yang tidak cukup kuat di antara lapisan. Namun, metode tersebut mengalami kegagalan sehingga pemisahan lapisan tidak terjadi, bahkan struktur planarnya hancur. Kegagalan tersebut membuktikan bahwa ikatan hidrogen dan ikatan kovalen antar lapisan g- $_{3} \mathrm{~N}_{4}$ tidak sekuat ikatan hidrogen dan ikatan kovalen pada lapisan grafit $[16,14]$.

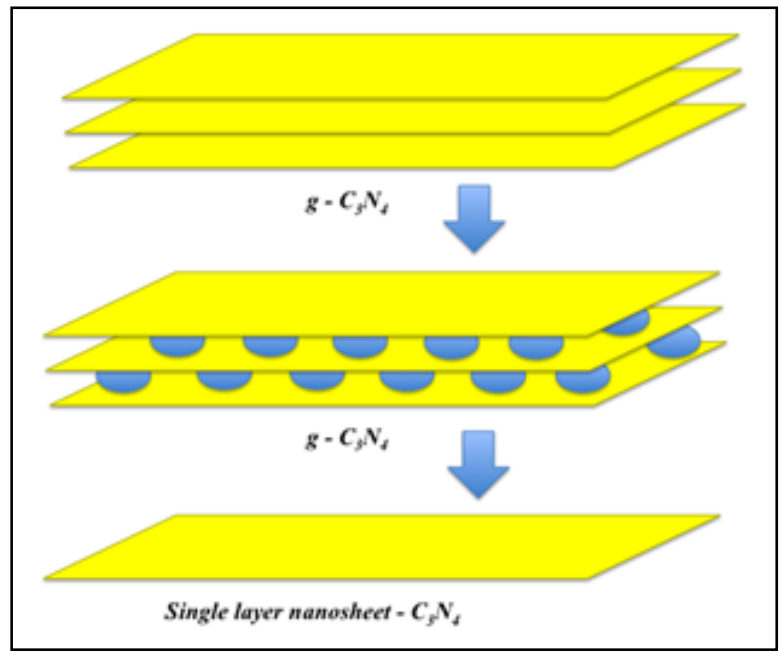

Gambar 1. Ilustrasi Proses Pemisahan Lapisan g- $\mathrm{C}_{3} \mathrm{~N}_{4}$ [16]

Jika dibandingkan dengan g- $\mathrm{C}_{3} \mathrm{~N}_{4}$ bulk, g- $\mathrm{C}_{3} \mathrm{~N}_{4}$ nanosheets memiliki permukaan yang lebih luas $\left(306 \mathrm{~m}^{2} / \mathrm{g}\right)$, band gap yang lebih besar $(0,2 \mathrm{Ev})$, serta kemampuan transfer elektron yang lebih tinggi [15]. Katalis $\mathrm{g}_{-} \mathrm{C}_{3} \mathrm{~N}_{4}$ nanosheets dapat terbentuk melalui proses oksidasi termal dengan menghasilkan ketebalan $2 \mathrm{~nm}$. Akan tetapi, proses tersebut sangat sulit dilakukan. Pemanasan g$\mathrm{C}_{3} \mathrm{~N}_{4}$ bulk dengan suhu $500{ }^{\circ} \mathrm{C}$ selama 2 jam hanya menghasilkan 6-7 lapisan g- $\mathrm{C}_{3} \mathrm{~N}_{4}$ nanosheet. Dalam proses ini, lama waktu pemanasan memegang peranan penting dalam pemisahan lapisan $\mathrm{g}$ $\mathrm{C}_{3} \mathrm{~N}_{4}$ bulk [17]. Semakin tinggi temperatur dalam proses pemisahan, luas permukaan $\mathrm{g}_{-} \mathrm{C}_{3} \mathrm{~N}_{4}$ nanosheet semakin kecil [18].

Usaha pemisahan $\mathrm{g}-\mathrm{C}_{3} \mathrm{~N}_{4}$ bulk berbentuk cair juga kerap dilakukan untuk mendapatkan $\mathrm{g}-\mathrm{C}_{3} \mathrm{~N}_{4}$ nanosheets. Metode ini biasanya menggunakan larutan asam kuat sebagai bahan penghancur ikatan antar lapisan dengan prosedur tertentu [19, 20]. Proses pemisahan $\mathrm{g}_{-} \mathrm{C}_{3} \mathrm{~N}_{4}$ bulk juga dapat dilakukan dengan larutan organik seperti isopropanol, etanol, dimetil formamida dan tetrahydrofuran [21]. Xu dan tim berhasil membuat satu lapis $\mathrm{g}-\mathrm{C}_{3} \mathrm{~N}_{4}$ nanosheet hanya dengan metode pemisahan sederhana menggunakan $\mathrm{H}_{2} \mathrm{SO}_{4} 98 \%$ sebagai bahan pencuci $[15,16]$. Dalam prosedur tersebut, konsentrasi larutan asam yang tinggi sangat penting dalam pembuatan $\mathrm{g}-\mathrm{C}_{3} \mathrm{~N}_{4}$ nanosheets. Penambahan tahapan 
ultrasonic yang kontinyu juga dapat membuat proses pemisahan menjadi lebih efektif. Di dan tim berhasil mengkonstruksi titik kuantum ${ }_{\mathrm{g}}-\mathrm{C}_{3} \mathrm{~N}_{4} / \mathrm{SnS}_{2}$ melalui metode sederhana dengan hasil kemampuan mereduksi $\mathrm{CO}_{2}$ yang luar biasa [22].

Berbeda dengan metode-metode sebelumnya yang menggunakan $\mathrm{g}-\mathrm{C}_{3} \mathrm{~N}_{4}$ bulk untuk mendapatkan $\mathrm{g}-\mathrm{C}_{3} \mathrm{~N}_{4}$ nanosheets, Lu dan tim nya menyederhanakan proses tersebut dengan membuat $\mathrm{g}-\mathrm{C}_{3} \mathrm{~N}_{4}$ nanosheets dengan satu tahap dari bahan baku dicynamide [23]. Komposisi yang tepat antara dicynamide dan ammonium klorida memegang peranan penting dalam pembuatan g$\mathrm{C}_{3} \mathrm{~N}_{4}$ nanosheets berkualitas tinggi. $\mathrm{NH}_{4} \mathrm{Cl}$ berperan sebagai sumber dinamik gas, dan sebagai fasilitator pembentukan $\mathrm{g}-\mathrm{C}_{3} \mathrm{~N}_{4}$ nanosheets yang sangat tipis.

\subsection{Sintesis Satu Tahap g- $\mathrm{C}_{3} \mathbf{N}_{4}$ Nanosheets}

Pada umumnya metode sintesis pembuatan carbon nitride nanosheets dibagi menjadi 2 tahap yaitu one step method (satu tahap) dan two steps methods (dua tahap). Metode dua tahap dilakukan dengan membuat carbon nitride bulk terlebih dahulu. Kemudian dilakukan modifikasi penambahan senyawa untuk membantu memecah ikatan gaya Van Der Waals menjadi nanosheets. Metode sintesis dua tahap merupakan metode yang paling sering digunakan dikarenakan mempunyai tingkat keberhasilan terbentuknya $\mathrm{g}_{-} \mathrm{C}_{3} \mathrm{~N}_{4}$ Nanosheets yang tinggi. Selain itu metode ini juga memiliki banyak variasi. Namun seiring berkembangnya zaman, peneliti menemukan metode sintesis yang lebih mudah dan simpel yaitu one step method. Metode satu tahap ini tergolong mudah dikarenakan dilakukan tanpa menambahkan doping seperti yang dilakukan pada sintesis dua tahap. Pada sintesis satu tahap, katalis $\mathrm{g}_{-} \mathrm{C}_{3} \mathrm{~N}_{4}$ nanosheets dapat terbentuk dengan satu proses tahapan yaitu proses pemanasan atau pirolisis [23]. Proses pemanasan ini dilakukan di dalam furnace dengan variasi suhu dan waktu yang berbeda. Hal tersebut bergantung pada senyawa prekursor yang digunakan.

Katalis $\mathrm{g}_{-} \mathrm{C}_{3} \mathrm{~N}_{4}$ nanosheets dapat terbentuk secara spontan hanya dengan mencampurkan senyawa melamin dan ammonium sulfat dalam jumlah yang sama secara homogen. Kemudian dikalsinasi pada suhu $600{ }^{\circ} \mathrm{C}$ selama 2 jam dengan furnace. Pada proses polimerisasi melamin, ammonium sulfat dapat terurai menjadi gas $\mathrm{NH}_{3}$ (g) dan gelembung $\mathrm{SO}_{2}$ (g) tanpa perlu mengeluarkan energi ekstra, didapatkan hasil fabrikasi g- $\mathrm{C}_{3} \mathrm{~N}_{4}$ nanosheets. Percobaan sederhana ini menyajikan beberapa keuntungan yaitu biaya hemat, efisiensi yang tinggi dan dapat diproduksi skala besar [24]. Ding dan tim mensintesis $\mathrm{g}-\mathrm{C}_{3} \mathrm{~N}_{4}$ nanosheets dari campuran prekursor melamin dan asam sianurat dipanaskan pada suhu $550{ }^{\circ} \mathrm{C}$ selama 4 jam. $\mathrm{g}-\mathrm{C}_{3} \mathrm{~N}_{4}$ nanosheets yang terbentuk memiliki kinerja yang baik dalam meremediasi limbah fenol [25]. Ringkasan metode-metode sintesis Carbon nitride Nanosheets disajikan pada Tabel 1.

Tabel 1. Metode-metode sintesis Carbon nitride Nanosheets

\begin{tabular}{|c|c|c|c|}
\hline Prekursor & Metode & Prosedur Sintesis & Referensi \\
\hline $\begin{array}{l}\text { Dicyanamide dan } \\
\text { ammonium } \\
\text { klorida }\end{array}$ & Metode satu tahap & $\begin{array}{c}\text { Campuran dari dicyanamide dan } \\
\text { ammonium klorida dipanaskan pada } \\
\text { suhu } 550{ }^{\circ} \mathrm{C} \text { selama } 4 \text { jam }\end{array}$ & [23] \\
\hline $\begin{array}{c}\mathrm{g}-\mathrm{C}_{3} \mathrm{~N}_{4} \text { berbasis } \\
\text { thiurea }\end{array}$ & $\begin{array}{l}\text { Exfoliation thermal } \\
\text { dari } \mathrm{g}-\mathrm{C}_{3} \mathrm{~N}_{4} \text { bulk } \\
\text { (sintesis dua tahap) }\end{array}$ & $\begin{array}{c}\text { Variasi suhu } 450{ }^{\circ} \mathrm{C}, 500{ }^{\circ} \mathrm{C} \text {, dan } 550^{\circ} \mathrm{C} \\
\text { selama } 2 \text { jam }\end{array}$ & [19] \\
\hline $\begin{array}{c}\mathrm{g}-\mathrm{C}_{3} \mathrm{~N}_{4} \text { bulk } \\
\text { berbasis melamin }\end{array}$ & $\begin{array}{l}\text { Exfoliation dari g- } \\
\mathrm{C}_{3} \mathrm{~N}_{4} \text { jenis bulk } \\
\text { (sintesis dua tahap) }\end{array}$ & $\begin{array}{c}\text { Katalis g- } \mathrm{C}_{3} \mathrm{~N}_{4} \text { bulk dicampur dengan } \\
\mathrm{H}_{2} \mathrm{SO}_{4} \text { dan } \mathrm{HNO}_{3} \text {, lalu suspense yang } \\
\text { terbentuk diaduk selama } 5 \text { jam pada } \\
\text { suhu ruangan kemudian disentrifugasi } \\
\text { pada dengan kecepatan } 13.000 \text { rpm. } \\
\text { Sampel kemudian dicuci dengan aquades } \\
\text { hingga mencapai pH } 7\end{array}$ & {$[21]$} \\
\hline $\begin{array}{l}\text { Melamin dan } \\
\text { asam sianurat }\end{array}$ & Sintesis satu tahap & $\begin{array}{c}\text { g- } \mathrm{C}_{3} \mathrm{~N}_{4} \text { disintesis menggunakan melamin } \\
\text { dan asam sianurat sebagai bahan awal } \\
\text { melalui tahapan pendekatan pemanasan. } \\
\text { Bahan dipanaskan hingga } 550^{\circ} \mathrm{C} \text { dengan } \\
\text { laju pemanasan } 2{ }^{\circ} \mathrm{C} / \text { menit dan ditahan } \\
\text { pada suhu ini selama } 4 \text { jam }\end{array}$ & [25] \\
\hline $\begin{array}{l}\text { Melamin dan } \\
\text { ammonium sulfat }\end{array}$ & Sintesis satu tahap & $\begin{array}{c}\text { g- } \mathrm{C}_{3} \mathrm{~N}_{4} \text { disintesis dengan mencampurkan } \\
\text { melamin dan amonium sulfat. kemudian } \\
\text { dikalsinasi pada } 600{ }^{\circ} \mathrm{C} \text { selama } 2 \text { jam } \\
\text { dengan laju } 2{ }^{\circ} \mathrm{C} / \text { menit. }\end{array}$ & [24] \\
\hline
\end{tabular}


Pada ulasan ini tim peneliti berusaha meningkatkan performa dari carbon nitride nanosheet dengan metode satu tahap dengan campuran prekursor melamin dan ammonium klorida yang belum pernah diujikan sebelumnya sehingga mampu menghasilkan carbon nitride dengan layer yang lebih tipis dari hasil penelitian yang pernah dilakukan. Diharapkan layer yang lebih tipis ini mampu meningkatkan performa fotokatalis carbon nitride yang ada. Ammonium klorida bertindak sebagai bahan pelengkap yang dapat memberikan template gas dinamis dan dapat membantu pembentukan lapisan yang sangat tipis dari $\mathrm{g}_{-} \mathrm{C}_{3} \mathrm{~N}_{4}$ nanosheets.

\subsection{Pemanfaatan Pemanfaatan $\mathrm{g}-\mathrm{C}_{3} \mathrm{~N}_{4}$ Nanosheets Untuk Fotoremediasi Limbah Pewarna Organik}

Dengan dibantu oleh cahaya tampak atau sinar ultraviolet, katalis $\mathrm{g}_{-} \mathrm{C}_{3} \mathrm{~N}_{4}$ nanosheet mempunyai kemampuan untuk meremediasi limbah organik salah satunya limbah pewarna. Proses fotoremediasi limbah organik secara umum dapat disimpulkan menjadi 5 tahap seperti pada Gambar 2 [2].

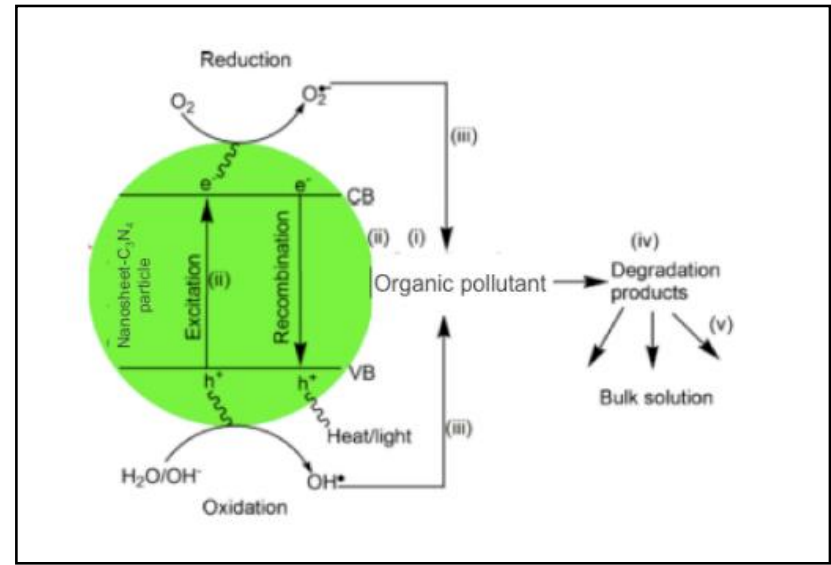

Gambar 2. Ilustrasi Proses Fotoremediasi Limbah Organik [2]

Terdapat 5 langkah dalam proses fotoremediasi limbah organik, yang pertama terjadi transfer massa limbah organik dari larutan limbah menuju permukaan $\mathrm{g}-\mathrm{C}_{3} \mathrm{~N}_{4}$ nanosheet melalui difusi. Selanjutnya terjadi proses adsorbsi limbah organik oleh $\mathrm{g}_{-} \mathrm{C}_{3} \mathrm{~N}_{4}$ nanosheet secara kontinu. Proses dilanjutkan dengan remediasi limbah organik. Selama proses fotoremediasi, akan terjadi proses desorpsi produk remediasi dari permukaan aktif fotokatalis. Terakhir produk fotoremediasi terdifusi dari interface fotokatalis menuju larutan.

Selama proses fotoremediasi berlangsung, cahaya menginduksi elektron untuk memacu perubahan pita valensi menuju pita konduksi, menghasilkan lubang positif dalam pita valensi yang disebut sebagai band gap. Pembentukan lubang positif dan negatif tersebut menyebabkan reaksi reduksi-oksidasi berlangsung di permukaan semikonduktor. Dalam proses ini, oksigen teroksidasi menjadi $\mathrm{O}_{2} *$, sementara $\mathrm{H}_{2} \mathrm{O}$ dari larutan berubah menjadi hydroxyl $\left(\mathrm{OH}^{*}\right)$. Kedua elemen tersebut dapat memproses zat organik dalam limbah dengan membentuk produk remediasi yang lebih aman untuk dibuang ke lingkungan. Dalam beberap kasus pengolahan limbah industri tertentu, produk remediasi dapat berupa zat pewarna rhodamin $\mathrm{B}$, methylene blue, methyl orange, dan lain-lain.

Beberapa uji laboratorium telah dilakukan untuk menguji kemampuan $\mathrm{g}-\mathrm{C}_{3} \mathrm{~N}_{4}$ nanosheets dalam meremediasi limbah organik. Tabel 2 menunjukkan performa beberapa proses dalam meremediasi macam-macam limbah dengan beberapa perbedaan metode persiapan dan bahan baku. Proses fotoremediasi banyak dilakukan menggunakan cahaya tampak karena kepraktisan dalam instalasi dan dapat dikomersialkan dengan biaya yang lebih murah karena dapat diganti dengan cahaya matahari. Jika dibandingkan dengan $\mathrm{g}_{-} \mathrm{C}_{3} \mathrm{~N}_{4}$ bulk, performa $\mathrm{g}-\mathrm{C}_{3} \mathrm{~N}_{4}$ nanosheets selalu lebih baik karena luas permukaannya yang lebih besar, struktur pita yang lebih baik, serta mobilitas elektron yang lebih tinggi [26].

Penambahan $\mathrm{Sn}^{3+}$ atau nanopartikel Au sebagai doping bisa meningkatkan performa dari $\mathrm{g}_{-} \mathrm{C}_{3} \mathrm{~N}_{4}$ nanosheet dalam proses fotoremediasi limbah pewarna [13]. Doping tersebut dapat membantu proses fotoremediasi limbah organik (langkah 3), dengan berperan sebagai penangkap elektron untuk memisahkan pasangan lubang elektron dan meningkatkan proses transfer elektron antar lapisan [27]. 
Tabel 2. Kumpulan performa fotokatalis $\mathrm{g}-\mathrm{C}_{3} \mathrm{~N}_{4}$ nanosheets untuk fotoremediasi limbah

\begin{tabular}{|c|c|c|c|c|c|}
\hline Fotokatalis & Aplikasi & $\begin{array}{l}\text { Komposisi } \\
\text { katalis }\end{array}$ & $\begin{array}{l}\text { Sumber } \\
\text { cahaya }\end{array}$ & $\begin{array}{l}\begin{array}{c}\text { Rasio fotodegradasi } \\
\text { limbah }\end{array} \\
\frac{C_{\text {init }}-C_{\text {final }}}{C_{\text {init }}} \times 100 \%\end{array}$ & Peneliti \\
\hline $\begin{array}{c}\mathrm{g}-\mathrm{C}_{3} \mathrm{~N}_{4} \\
\text { nanosheet }\end{array}$ & Rhodamin B & $\begin{array}{c}40 \mathrm{mg} \text { untuk } \\
\text { degradasi } 80 \mathrm{~mL} \\
\text { larutan } \mathrm{RhB}(10 \\
\mathrm{ppm})\end{array}$ & $\begin{array}{l}\text { Lampu } \\
\text { Xenon } \\
300 \mathrm{~W}\end{array}$ & $\begin{array}{c}40 \%(\text { bulk }) \\
100 \% \text { (nanosheet) }\end{array}$ & [28] \\
\hline $\begin{array}{l}{\mathrm{g}-\mathrm{C}_{3} \mathrm{~N}_{4-}}_{\text {nanosheetl }} \\
\mathrm{CuCr}_{2} \mathrm{O}_{4}\end{array}$ & $\begin{array}{l}\text { RhB, MB, } \\
\text { dan fenol }\end{array}$ & $\begin{array}{l}0,1 \text { g untuk } 250 \\
\text { mL limbah }\end{array}$ & $\begin{array}{l}\text { Lampu } \\
\text { LED } 50 \\
\text { W }\end{array}$ & $\begin{array}{l}11,8 \mathrm{x} \text { lebih besar dibanding } \\
\text { bulk }(\mathrm{RnB}), 4,1 \mathrm{x} \text { lebih besar } \\
\text { dibanding bulk (MB), dan } \\
7.5 \mathrm{x} \text { lebih besar dibanding } \\
\text { bulk (fenol) }\end{array}$ & [29] \\
\hline $\begin{array}{l}\mathrm{Sm}^{3+} \text {-doped } \mathrm{g}- \\
\mathrm{C}_{3} \mathrm{~N}_{4} \text { nanosheet }\end{array}$ & $\begin{array}{l}\text { Rhodamin } \mathrm{B} \\
\text { (RhB), } \\
\text { methylene } \\
\text { blue }(\mathrm{MB}), \\
\text { dan eosin } \\
\text { yellow (EY) }\end{array}$ & $\begin{array}{l}0,01 \mathrm{~g} \text { untuk } 20 \mathrm{ml} \\
\text { pewarna dengan } \\
\text { konsentrasi } 15 \mathrm{ppm}\end{array}$ & $\begin{array}{l}\text { Simulator } \\
\text { Heber } \\
\text { solar }\end{array}$ & $\begin{array}{l}\text { RhB: } ~ 40 \% \text { (bulk); } 100 \% \\
\text { (CN-0.02 wt } \% \mathrm{Sm}^{3+} \text { ) } \\
\text { MB: } ~ 70 \% \text { (bulk); 90\% } \\
\text { (CN-0.02 wt } \% \mathrm{Sm}^{3+} \text { ) } \\
\text { EY: 40\% (bulk); 100\% } \\
\text { (CN-0.02 wt } \% \mathrm{Sm}^{3+} \text { ) }\end{array}$ & {$[30]$} \\
\hline $\begin{array}{c}\text { Oxygen-doped } \\
\text { Nanosheet }-\mathrm{C}_{3} \mathrm{~N}_{4} \\
\text { tipis berpori }\end{array}$ & $\begin{array}{l}\text { Methyl } \\
\text { orange }\end{array}$ & $\begin{array}{c}0.05 \mathrm{~g} \text { untuk } \\
\text { degradasi } 50 \mathrm{mg} \\
\text { MO }\end{array}$ & $\begin{array}{l}\text { Lampu } \\
\text { Xenon } \\
300 \mathrm{~W}\end{array}$ & $\begin{array}{c}0.96 \% \text { (Bulk); } \\
\sim 60.82 \% \text { (nanosheet) }\end{array}$ & {$[21]$} \\
\hline $\begin{array}{c}\mathrm{g}-\mathrm{C}_{3} \mathrm{~N}_{4} \\
\text { nanosheet } \\
\text { dengan } \\
\text { penambahan } \mathrm{Au}\end{array}$ & $\begin{array}{l}\text { Methyl } \\
\text { orange }\end{array}$ & $\begin{array}{c}45 \mathrm{mg} \text { untuk } 15 \mathrm{ml} \\
\text { pewarna dengan } \\
\text { konsentrasi } 10 \\
\mathrm{mg} / \mathrm{L}\end{array}$ & $\begin{array}{l}\text { Lampu } \\
\text { Xenon } \\
500 \mathrm{~W}\end{array}$ & $\begin{array}{c}<10 \%(\text { bulk }) \\
>90 \%\left(\text { AuNP/g-C } \mathrm{C}_{3} \mathrm{~N}_{4}\right. \\
\text { nanosheets })\end{array}$ & [13] \\
\hline $\begin{array}{c}\mathrm{g}-\mathrm{C}_{3} \mathrm{~N}_{4} \\
\text { nanosheet }\end{array}$ & Fenol & $1 \mathrm{~g}$ untuk $1 \mathrm{~L}$ fenol & $\begin{array}{l}\text { Cahaya } \\
\text { UV }\end{array}$ & $\begin{array}{c}\sim 30 \% \text { (bulk) } \\
\sim 100 \% \text { (nanosheet), }\end{array}$ & {$[18]$} \\
\hline
\end{tabular}

Pada Gambar 3 tersaji grafik peforma katalis carbon nitride nanosheets dalam fotoremediasi limbah pewarna rhodamin $\mathrm{B}$, menunjukan bahwa perbedaan sintesis katalis carbon nitride nanosheets secara satu tahap dan dua tahap tidak berpengaruh terhadap penurunan kadar konsentrasi rhodamin-B. Kedua metode sintesis katalis menunjukkan peforma yang baik dalam meremediasi limbah pewarna rhodamin B.

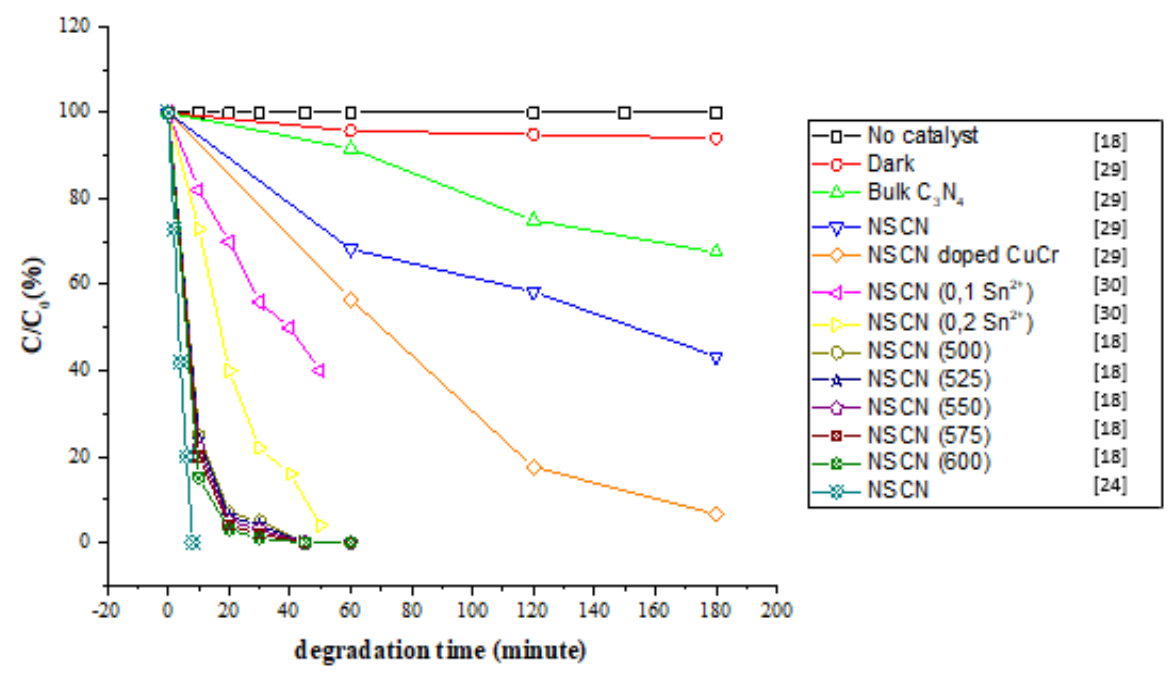

Gambar 3. Grafik Performa Carbon Nitride Nanosheets dalam Degradasi Limbah Pewarna Rhodamin B

Merujuk dari kemiripan sifat antara melamin dengan dicyanamide dan ammonium sulfat dengan ammonium klorida, dapat disimpulkan $\mathrm{g}_{-} \mathrm{C}_{3} \mathrm{~N}_{4}$ nanosheets dengan prekursor melamin dan ammonium klorida memiliki kemampuan yang cukup baik dalam meremediasi limbah pewarna dan limbah organik lainnya seperti rhodamin $\mathrm{B}$, methylene blue, dan methyl orange. 


\section{Kesimpulan}

Carbon nitride nanosheet memiliki performa yang tinggi dan ketahanan fotokatalis dalam proses fotoremediasi limbah organik yang dapat dimanfaatkan dalam berbagai macam sektor pengolahan limbah seperti penanganan limbah pewarna organik. Salah satu inovasi terbaru yang dapat digunakan yaitu penggunaan campuran prekursor melamin dan ammonium klorida sebagai prekursor fotokatalis Carbon nitride nanosheet. Hal ini dikarenakan kedua bahan tersebut memiliki karakteristik yang cocok sebagai sumber dinamik gas dan fasilitator pembentukan Carbon nitride nanosheets yang sangat tipis sehingga dapat menigkatkan efisiensi dalam fotoremediasi limbah pewarna organik.

\section{Ucapan Terima Kasih}

Peneliti mengucapkan terimakasih atas bantuan pendanaan penelitian oleh Kementerian Pendidikan dan Kebudayaan dengan nomor kontrak 1686/E2/TU/2020 serta didukung oleh Universitas Sebelas Maret Surakarta.

\section{Daftar Pustaka}

[1] M. Tahir et al., "Bifunctional catalysts of Co3O4@GCN tubular nanostructured (TNS) hybrids for oxygen and hydrogen evolution reactions," Nano Res., vol. 8, no. 11, pp. 3725-3736, 2015, doi: $10.1007 / \mathrm{s} 12274-015-0872-1$

[2] G. Mamba and A. K. Mishra, "Graphitic carbon nitride (g-C3N4) nanocomposites: A new and exciting generation of visible light driven photocatalysts for environmental pollution remediation," Appl. Catal. B Environ., vol. 198, pp. 347-377, 2016, doi: 10.1016/j.apcatb.2016.05.052.

[3] M. Tahir et al., "Tubular graphitic-C3N4: A Prospective material for energy storage and green photocatalyst," J. Mater. Chem. A, no. 44, pp. 13949-13955, 2013.

[4] A. W. Budiman et al., "Review of Acetic Acid Synthesis from Various Feedstocks Through Different Catalytic Processes," Catal. Surv. from Asia, vol. 20, no. 3, pp. 173-193, 2016, doi: 10.1007/s10563016-9215-9.

[5] S. Sadjadi, M. M. Heravi, and M. Malmir, "Pd@HNTs-CDNS-g-C3N4: A novel heterogeneous catalyst for promoting ligand and copper-free Sonogashira and Heck coupling reactions, benefits from halloysite and cyclodextrin chemistry and g-C3N4 contribution to suppress Pd leaching," Carbohydr. Polym., vol. 186, no. November 2017, pp. 25-34, 2018, doi: 10.1016/j.carbpol.2018.01.023.

[6] Q. Su, J. Sun, J. Wang, Z. Yang, W. Cheng, and S. Zhang, "Urea-derived graphitic carbon nitride as an efficient heterogeneous catalyst for $\mathrm{CO} 2$ conversion into cyclic carbonates," Catal. Sci. Technol., vol. 4, no. 6, pp. 1556-1562, 2014, doi: 10.1039/c3cy00921a.

[7] S. Zhao et al., "Fabrication of sandwich-structured g-C3N4/Au/BiOCl Z-scheme photocatalyst with enhanced photocatalytic performance under visible light irradiation," J. Mater. Sci., vol. 53, no. 8, pp. 6008-6020, 2018, doi: 10.1007/s10853-018-1995-z.

[8] X. Wen, N. Sun, Y. Tan, W. Wang, C. Yan, and H. Wang, "One-step synthesis of petals-like graphitic carbon nitride nanosheets with triazole defects for highly improved photocatalytic hydrogen production," Int. J. Hydrogen Energy, vol. 44, no. 5, pp. 2675-2684, 2019, doi: 10.1016/j.ijhydene.2018.11.117.

[9] B. Lin, H. An, X. Yan, T. Zhang, J. Wei, and G. Yang, "Fish-scale structured g-C3N4 nanosheet with unusual spatial electron transfer property for high-efficiency photocatalytic hydrogen evolution," Appl. Catal. B Environ., vol. 210, pp. 173-183, 2017, doi: 10.1016/j.apcatb.2017.03.066.

[10] A. W. Budiman, M. J. Choi, and A. Nur, "Catalytic performance of heterogeneous Rh/C3N4 for the carbonylation of methanol," AIP Conf. Proc., vol. 1931, 2018, doi: 10.1063/1.5024069.

[11]I. F. Teixeira, E. C. M. Barbosa, S. C. E. Tsang, and P. H. C. Camargo, "Carbon nitrides and metal nanoparticles: From controlled synthesis to design principles for improved photocatalysis," Chem. Soc. Rev., vol. 47, no. 20, pp. 7783-7817, 2018, doi: 10.1039/c8cs00479j.

[12]N. D. Shcherban et al., "Melamine-derived graphitic carbon nitride as a new effective metal-free catalyst for Knoevenagel condensation of benzaldehyde with ethylcyanoacetate," Catal. Sci. Technol., vol. 8, no. 11, pp. 2928-2937, 2018, doi: 10.1039/c8cy00253c. 
[13]H. Huang et al., "Template-free precursor-surface-etching route to porous, thin g-C3N4 nanosheets for enhancing photocatalytic reduction and oxidation activity," J. Mater. Chem. A, vol. 5, no. 33, pp. 1745217463, 2017, doi: 10.1039/c7ta04639a.

[14]E. Boorboor Azimi, A. Badiei, and J. B. Ghasemi, "Efficient removal of malachite green from wastewater by using boron-doped mesoporous carbon nitride," Appl. Surf. Sci., vol. 469, no. April 2018, pp. 236-245, 2019, doi: 10.1016/j.apsusc.2018.11.017.

[15]P. Niu, L. Zhang, G. Liu, and H. M. Cheng, "Graphene-like carbon nitride nanosheets for improved photocatalytic activities," Adv. Funct. Mater., vol. 22, no. 22, pp. 4763-4770, 2012, doi: 10.1002/adfm.201200922.

[16]J. Xu, L. Zhang, R. Shi, and Y. Zhu, "Chemical exfoliation of graphitic carbon nitride for efficient heterogeneous photocatalysis," J. Mater. Chem. A, vol. 1, no. 46, pp. 14766-14772, 2013, doi: 10.1039/c3ta13188b.

[17] J. Zhang, Y. Chen, and X. Wang, "Two-dimensional covalent carbon nitride nanosheets: Synthesis, functionalization, and applications," Energy Environ. Sci., vol. 8, no. 11, pp. 3092-3108, 2015, doi: 10.1039/c5ee01895a.

[18]L. Svoboda et al., "Graphitic carbon nitride nanosheets as highly efficient photocatalysts for phenol degradation under high-power visible LED irradiation," Mater. Res. Bull., vol. 100, no. September 2017 , pp. 322-332, 2018, doi: 10.1016/j.materresbull.2017.12.049.

[19]F. Dong, Y. Li, Z. Wang, and W. K. Ho, "Enhanced visible light photocatalytic activity and oxidation ability of porous graphene-like g-C3N4nanosheets via thermal exfoliation," Appl. Surf. Sci., vol. 358, pp. 393-403, 2015, doi: 10.1016/j.apsusc.2015.04.034.

[20]X. She et al., "Template-free synthesis of 2D porous ultrathin nonmetal-doped g-C3N4 nanosheets with highly efficient photocatalytic H2 evolution from water under visible light," Appl. Catal. B Environ., vol. 187, pp. 144-153, 2016, doi: 10.1016/j.apcatb.2015.12.046.

[21]X. She et al., "Exfoliated graphene-like carbon nitride in organic solvents: Enhanced photocatalytic activity and highly selective and sensitive sensor for the detection of trace amounts of $\mathrm{Cu} 2+$," J. Mater. Chem. A, vol. 2, no. 8, pp. 2563-2570, 2014, doi: 10.1039/c3ta13768f.

[22] T. Di, B. Zhu, B. Cheng, J. Yu, and J. Xu, "A direct Z-scheme g-C3N4/SnS2 photocatalyst with superior visible-light CO2 reduction performance," J. Catal., vol. 352, pp. 532-541, 2017, doi: 10.1016/j.jcat.2017.06.006.

[23] X. Lu, K. Xu, P. Chen, K. Jia, S. Liu, and C. Wu, "Facile one step method realizing scalable production of g-C3N4nanosheets and study of their photocatalytic H2evolution activity," J. Mater. Chem. A, vol. 2, no. 44, pp. 18924-18928, 2014, doi: 10.1039/c4ta04487h.

[24] W. Iqbal, B. Qiu, J. Lei, L. Wang, J. Zhang, and M. Anpo, “One-step large-scale highly active g-C3N4 nanosheets for efficient sunlight-driven photocatalytic hydrogen production," Dalt. Trans., vol. 46, no. 32, pp. 10678-10684, 2017, doi: 10.1039/c7dt00849j.

[25] W. Ding, S. Liu, and Z. He, “One-step synthesis of graphitic carbon nitride nanosheets for efficient catalysis of phenol removal under visible light," Cuihua Xuebao/Chinese J. Catal., vol. 38, no. 10, pp. 1711-1718, 2017, doi: 10.1016/S1872-2067(17)62907-3.

[26]X. Wei et al., "Facile: In situ synthesis of plasmonic nanoparticles-decorated g-C3N4/TiO2 heterojunction nanofibers and comparison study of their photosynergistic effects for efficient photocatalytic H2 evolution," Nanoscale, vol. 8, no. 21, pp. 11034-11043, 2016, doi: 10.1039/c6nr01491g.

[27] S. Xie, Y. Wang, Q. Zhang, W. Deng, and Y. Wang, "MgO- and Pt-promoted TiO2 as an efficient photocatalyst for the preferential reduction of carbon dioxide in the presence of water," ACS Catal., vol. 4, no. 10, pp. 3644-3653, 2014, doi: 10.1021/cs500648p.

[28] Q. Lin, L. Li, S. Liang, M. Liu, J. Bi, and L. Wu, "Efficient synthesis of monolayer carbon nitride 2D nanosheet with tunable concentration and enhanced visible-light photocatalytic activities," Appl. Catal. B Environ., vol. 163, pp. 135-142, 2015, doi: 10.1016/j.apcatb.2014.07.053. 
[29] A. Akhundi and A. Habibi-yangjeh, "Graphitic carbon nitride nanosheets decorated with $\mathrm{CuCr} 2 \mathrm{O} 4$ nanoparticles: Novel photocatalysts with high performances in visible light degradation of water pollutants Journal of Colloid and Interface Science Graphitic carbon nitride nanosheets decorat," no. November, pp. 2-3, 2017, doi: 10.1016/j.jcis.2017.06.025.

[30] J. Thomas, K. S. Ambili, and S. Radhika, "Synthesis of Sm3+-doped graphitic carbon nitride nanosheets for the photocatalytic degradation of organic pollutants under sunlight," Catal. Today, vol. 310, pp. 1118, 2018, doi: 10.1016/j.cattod.2017.06.029. 